Seyahat ve Otel İşletmeciliği Dergisi/

Journal of Travel and Hospitality Management

16 (1), 2019,106-120.

Gönderim Tarihi: 23.11.2018

Kabul Tarihi:08.02.2019

\title{
Bilişsel Uyumsuzluk Ölçeğinin Türkçeye Uyarlanması: Geçerlik ve Güvenirlik Çalışması ${ }^{\star}$
}

\section{Adaptation of the Cognitive Dissonance Scale into Turkish: The Validity and Reliability Study}

\author{
Dr. Esin YÜCEL \\ Akdeniz Üniversitesi \\ Akdeniz Uygarlıkları Araştırma Enstitüsü \\ E-posta: esinyucel@akdeniz.edu.tr
}

\author{
Prof. Dr. Beykan ÇizEL \\ Akdeniz Üniversitesi \\ Turizm Fakültesi \\ E-posta: beykan@akdeniz.edu.tr
}

\section{Öz}

Sweeney ve arkadaşlarının (2000) karar sonrası uyumsuzluğun duygusal ve bilişsel yönlerini ölçmek için geliştirdikleri Bilişsel Uyumsuzluk Ölçeği üç faktörlü bir yapı altında toplam 12 maddeden oluşmaktadır. Çalışmanın amacı, bu ölçeği Türkçe literatüre kazandırmaktır. Ölçek konaklama satın alımı yapan 290 (146 kadın, 144 erkek) otel müşterisine uygulanmıştır. Açımlayıcı faktör analizi sonucunda toplam açıklanan varyansın \%77,7 olduğu ve maddelerin üç alt boyut altında toplandığı saptanmıştır. Bu alt boyutlar; duygusal uyumsuzluk, satın almada akılcılık ve kandırılma endişesidir. Ölçeğin yapı geçerliliğini sağlamak için uygulanan doğrulayıcı faktör analizi sonucunda üç boyutlu bu yapının iyi uyum verdiği bulunmuştur. Ölçeğin güvenirlik analizi sonucunda iç tutarlılık katsayısı 0,93'tür. Duygusal boyut için iç tutarlılık katsayısı 0,87; satın almada akılcılık ve kandırıma endişesi boyutları için ise 0,91'dir. Bilişsel Uyumsuzluk Ölçeğinin Türkçe formunun kabul edilebilir değerlerde güvenilir ve geçerli bir ölçme aracı olduğu söylenebilir. Ülkemizde, satın alma ile ilgili deneyimler konusunda yapılacak araştırmalarda bu tür ölçeklere gereksinim vardır ve ölçeğin bu bağlamda yapılacak araştırmalarda kullanılabileceği umulmaktadır.

Anahtar Kelimeler: Ölçek Uyarlama, Bilişsel Uyumsuzluk Ölçeği, Festinger, Ölçek Geliştirme.

\begin{abstract}
The Cognitive Dissonance Scale developed by Sweeney and colleagues (2000) in order to measure the emotional and cognitive aspects of non-conformity after the decision is in English. It consists of 12 items in total under a three-factor structure. The aim of the study is to make this scale available in Turkish. The scale was applied to 290 (146 female, 144 male) hotel customers buying hotel accommodation. As a result of the exploratory factor analysis, it was found that the total explained variance was $77.7 \%$ and the items were collected under three subdimensions. These sub-dimensions are emotional dissonance, rationality in buying and anxiety of being defrauded. It was found that this three dimensional structure was conformed well as a result of confirmatory factor analysis applied to ensure the construct the validity of the scale. As a result of the reliability analysis of the scale, the internal consistency coefficient was 0.93 . The internal consistency coefficient for emotional dimension was 0.87 ; and 0.91 for the rationality in buying and anxiety of being defrauded. It can be said that the Turkish version of the Cognitive Dissonance Scale is a reliable and valid measurement tool in acceptable values. In our country, such scales are needed in researches about purchasing experience and it is hoped that the scale will contribute to the researches in this context.
\end{abstract}

Key Words: Adaptation of Scale, Cognitive Dissonance Scale, Festinger, Scale Development

*Bu çalışma Prof. Dr. Beykan ÇiZEL danışmanlığında, Esin Yücel tarafından Akdeniz Ün. Sosyal Bilimler Enstitüsü'nde 2017 yılında tamamlanan Doktora Tezinden üretilmiştir. 


\section{Giriş}

Festinger'in (1957) bireyin inandığı şey (beklentiler) ile bu inanca karşı çıkan bilgi (deneyimler) arasındaki tutarsızlık nedeniyle ortaya çıkan rahatsız edici duygu durumu olarak tanımladığı Bilişsel Uyumsuzluk, bireyin her türlü kararı sonrasında ortaya çıkabilir. Karar verme davranışı sonucunda vazgeçilen alternatiflerin olumlu yönleri ile seçilen alternatifin olumsuz yönlerinin birey üzerinde oluşturduğu olumsuz duygu durumu, bireyin kararını sorgulaması sonucunu beraberinde getirir.

Bu kararlar için aynı anda alınan iki davetten birini seçmek, iki iş teklifinden birini tercih etmek, üniversite sınavı sonucunda sıralamaya karar vermek, eviniz için alacağınız beyaz eşyanın herhangi bir markasına karar vermek ya da tatil için bir otele karar vermek gibi sayısız örnek verilebilir. Önemli olan nokta, bilişsel uyumsuzluk yaşanabilme intimalinden söz edebilmek için gerekli koşulların oluşmasıdır. Bunlar; kararın gönüllü olması (özgür seçim/sorumluluk), geri alınamaması ve birey için önemli olmasıdır (Cummings ve Venkatesan 1976; Sauter ve Sweeney, 2003). Karar bireye ait değilse, önemsiz ya da geri dönüşü yani iptali mümkün olan bir kararsa uyumsuzluk söz konusu değildir.

Bilişsel uyumsuzluk, tüketici kararları açısından ele alındığında karar verme ya da satın alma işleminden sonra hissedilen pişmanlık duygusu olarak tanımlanabilir (Oliver, 1997). Bu pişmanlığın nedeni kararı destekleyen ve desteklemeyen karşıt bilişsel unsurlardır. Uyumsuzluk, aynı zamanda bireyin satın aldığı hizmetin/ürünün beklediği gibi performans göstermeyeceği konusunda endişe etmesi ve/veya seçim şansını vazgeçtiği diğer alternatif(ler) lehinde kullanmış olması durumunda sahip olabileceği olumlu niteliklerden vazgeçtiği hissidir. Bu durum ürünün kullanımı ya da hizmetin deneyimlenmesi öncesinde ortaya çıkar ve kullanım ya da deneyim sonrasında memnuniyet ya da memnuniyetsizliği doğurur (Oliver, 1997; Sweeney vd., 2000; Bolia vd., 2016). Sweeney ve meslektaşlarına göre (2000) uyumsuzluk ve memnuniyet kavramları arasında önemli fark vardır. Uyumsuzluk karar sonrasında, memnuniyet ise performans/deneyim sonrası durum beklentilerle kıyaslandığında ortaya çıkar. Yani memnuniyet bilinen performansın ve beklentilerin kıyaslanmasına dayanırken uyumsuzluk bilinmeyen sonuçlarla ilgilidir. Aralarındaki bağlantı ise bilişsel uyumsuzluğun azaltılmasının müşteri memnuniyetinin oluşması için gerekli ön koşul olduğudur (Hausknecht vd., 1998). Yeniden satın alma niyeti, marka sadakati, şikâyet, iade davranışı ve sözleşme iptallerinin satın alma sonrası bilişsel uyumsuzlukla ilişkisini ortaya koyan araştırmalar da (Donnelly ve Ivancevich, 1970; Keng ve Liao, 2009) göz önüne alındığında, uyumsuzluğun azaltılmasına yönelik çabaların önemli olduğu düşünülmektedir.

Tüketici bir karar verdikten sonra bilişsel uyumsuzluğun olası üç etkisinden söz etmek mümkündür. Bu etkiler aynı zamanda bu çalışmanın konusu olan ölçeğin alt boyutlarını ortaya koymaktadır. Satın alma kararı sonrasında psikolojik rahatsızlığın (duygusal) yanı sıra diğer alternatifler arasından yapılan seçimin uygunluğu ve gerekliliği (satın almada akılcılık) sorgulanabilir. Ayrıca satış elemanının satış kararını etkileyip etkilemediği konusunda bilişsel rahatsızlık (kandırılma endişesi) hissedilebilir. Bunların tümünün aynı anda meydana gelmesi şart değildir. Bazı tüketiciler satın alma işlemi ile sonuçlanan kararlarının satış personelinin yönlendirmelerinden etkilendiğini düşünerek kararlarını sorgularken (kandırılma endişesi), bazıları ise aldıkları tüketim malzemesine ne derece intiyaçları olduğunu ya da marka tercihlerini (satın almada akılcılık) sorgulayabilirler (Bell, 1967). Burada önemli olan nokta tüm bu olasılıklar için kararın geri dönülemez, önemli ve özgürce alınmış bir karar olmasıdır. Yani bütün satın alma kararlarının uyumsuzluğa neden olacağını söylemek mümkün değildir (Oliver, 
1997). Örneğin günlük tüketim malzemelerinde söz konusu olamayan uyumsuzluk, özelliklere ve fiyatlara göre değişiklik gösteren farklı markalardaki dayanıklı tüketim malları satın alırken belirgindir (Menasco ve Hawkins 1978).

Bireyler seçimleri konusunda yanlış yapmış olabileceklerini hissettiklerinde ya da böyle olmasa bile vazgeçilen alternatifin cazip yönlerini ve seçilen alternatifin olumsuz sayılabilecek özelliklerini düşündüklerinde psikolojik dengeyi (iyi oluşu) sağlamak açısından bu uyumsuzluğu azaltmaya yönelik bilinçli ya da bilinç dışı olarak bireysel çaba göstereceklerdir (Festinger, 1957; Oliver, 1997). Bireysel çabaya örnek olarak kişinin kendini "seçiminin çok da kötü olmadığı" yönünde inandırmaya yönelik bilişsel manipülasyonları örnek verilebilir (Oliver, 1997). Bireyin uyumsuzluğunu azaltmaya yönelik bir başka durum ise sosyal destek görüp görmeyeceğidir. Sosyal destek için ise aynı ürünü kullanan ya da aynı hizmeti deneyimlemiş olan kişilerin olumlu telkinleri örnek verilebilir. Çünkü tüketiciler bir satın alma kararı verirken algıladıkları riski azaltma stratejisi olarak tavsiyelere güvenme yolunu kullanırlar (Kim, 2011). Aslında tüm bunların altında yatan sebep verilmiş olan kararla ilgili olarak bireyin güven eksikliğidir. Birey en iyi kararı vermiş olduğuna inanıyorsa ne bilişsel manipülasyona ne de sosyal desteğe intiyaç duyacaktır (Yücel, 2018; Yücel ve Çizel, 2018).

Tüketicilerin satın almadan sonra yaşadıkları uyumsuzluk, ürün iade isteklerinin, şikâyetlerin, olumsuz ağızdan ağıza iletişimin önemli nedenlerinden biridir (Milliman ve Decker, 1990). Aynı zamanda olumsuz ağızdan ağıza iletişim de bilişsel uyumsuzluk üzerinde etkilidir (Kim, 2011). Bu noktada sosyal destek olarak adlandırılabilecek olan 'işletmelerin satış sonrası tüketiciyle kurdukları iletişim' önemlidir. Tüketicinin seçimiyle ilgili olarak kendisini iyi hissetmesini sağlayacak, verilen kararın doğruluğuna yönelik bilgiler aktarmak kararla ilgili olarak ihtiyaç duyulan güveni artıracaktır. İşletmeler açısından satın alma kararlarında tüketici davranışlarını anlamak, müşterilerin bilişsel uyumsuzluk düzeylerini belirleyebilmek ve bu durum müşteri memnuniyetsizliğine dönüşmeden önlemler almak, müşteri memnuniyeti sonrasında yeniden satın alma davranışını ve nihayetinde marka sadakatini beraberinde getirecektir (Mittelstaedt, 1969; Hunt, 1970; Milliman ve Decker, 1990; Yücel ve Çizel, 2018). Ürün iade istekleri tüketicinin yaşadığı uyumsuzluğun sonucudur ve satın alma sonrası iletişim ürün iade isteklerini de azaltacaktır (Milliman ve Decker, 1990). Nitekim tüketicide ileride oluşması arzulanan tekrar seçim olasılığı için bilişsel uyumsuzluğun önemsenmesi, tüketicinin yaşadığı bu olumsuz duygu durumunun azaltılması için adımlar atılması, müşteri memnuniyetinin oluşması için gerekli ön koşuldur. Uyumsuzluk sürecini anlayan yöneticiler satış sonrası iletişime önem vermeli, tüketiciye yaptığı tercihin doğru olduğu yönünde uygun bilgiler sağlayarak yardımcı olmalıdırlar (Kotler ve Armstrong, 2012; Yücel ve Çizel, 2018).

Turizm sektörü açısından bilişsel uyumsuzluk ve sektörün özgün özellikleri arasında ilişki önemlidir. Fakat yapılan çalışmaların şaşırtıcı azlığı dikkat çekmektedir (Bawa ve Kansal, 2008; Tanford ve Montgomery, 2015). Seyahat için pek çok satın alma, iade edilemediği için uyumsuzluk daha olasıdır (Tanford ve Montgomery, 2015). Nitekim Bawa ve Kansal (2008) hizmet özellikleri ve türlerinin bilişsel uyumsuzluk olasılığını etkileyip etkilemediğini inceledikleri çalışmalarında, sektöre özel algılanan risk ve belirsizliğin büyük bir itici güç olarak karar vermede bilişsel uyumsuzluğa yol açtığını ortaya koymuşlardır.

Tüm bu bilgiler ışığında hizmet satın alan turist açısından tatilini geçireceği destinasyon ve konaklama işletmesinin seçiminin sorumluluk gerektiren ve önemli bir karar olduğu söylenebilir. Bilişsel uyumsuzluğun yaşanabileceği aşamalar, rezervasyon sonrası ve/veya konaklama işletmesine girişten sonraki aşamadır. Çünkü artık kararın 
geri alınması mümkün görünmemektedir. Daha sonraki günlerde ise hizmet deneyimlenecek ve sunulan hizmete dair kesin yargıyı ifade edecek olan memnuniyet veya memnuniyetsizlik ortaya çıkacaktır. Dolayısıyla bu araştırmanın örneklemi ve zamanlaması için işletmeye gelip bir fikir edinen ve diğer alternatiflerin değerlendirilmemesinin yarattığı etkinin ölçülebileceği bir gece konaklama yapan turistler tercih edilmiştir. Araştırmanın amacı Sweeney ve meslektaşlarının (2000) tüketiciyi anlayabilmek ve yönlendirebilmek adına karar sonrası uyumsuzluğun duygusal ve bilişsel yönlerini tespit etmek için geliştirdikleri Bilişsel Uyumsuzluk Ölçeğinin Türkçeye uyarlanmasıdır. Alanyazında bilişsel uyumsuzluğu ölçen bir başka ölçek de Koller ve Salzberger (2007) tarafından geliştirilen ölçektir. Sweeney ve meslektaşlarının (2000) geliştirdiği bilişsel uyumsuzluk ölçeği Koller ve Salzberger (2007) tarafından geliştirilen ölçekten farklı olarak uyumsuzluğun duygusal ve bilişsel yönlerini bir arada değerlendirme olanağı sunmaktadır. Alanyazında bu konuda Türkçe olarak geliştirilmiş ya da Türkçeye uyarlanmış bir ölçeğe rastlanılmamıştır. Bu sebeple Bilişsel Uyumsuzluk Ölçeğinin Türkçeye kazandırımasının alanyazın için önemli olduğu ve alana katkı sağlayacağı düşünülmektedir.

\section{Yöntem}

\subsection{Bilişsel Uyumsuzluk Ölçeği (BUÖ)}

Sweeney ve meslektaşları (2000), 22 ifade olarak geliştirdikleri ölçekte üç boyut belirlemişlerdir. Ölçeğin boyutları duygusal uyumsuzluk, satın almada akılcılık ve kandırılma endişesidir. Duygusal boyut (15 madde) satın alma kararı sonrasında psikolojik rahatsızlığı, satın almada akılcılık (4 madde) alımın gerekliliği veya diğer alternatifler arasından yapılan seçimin uygunluğu konusundaki bilişsel rahatsızlığı ve son olarak kandırılma endişesi ( 3 madde), satış elemanının satış kararını etkileyip etkilemediği konusundaki bilişsel rahatsızlığı temsil etmektedir. Bu boyut özgün kararda yer alan biliş yerine bireylere kararı dış etkilere bağlama imkânı vererek dolaylı yoldan bilişsel uyumsuzluğu ölçer (Sweeney vd., 2000; Telci vd., 2011). Daha sonra bu ölçek Sweeney ve Soutar (2006) tarafından kısaltılmış ve 15 maddelik duygusal boyut 5 maddeye indirilerek uygulama açısından daha pratik hale getirilmiştir. Duygusal uyumsuzluk boyutunun kısa formunun korelâsyonunun .97 olması kullanırken hiçbir bilgi kaybı olmadığını göstermiştir (Sweeney ve Soutar, 2006). Araştırmacıların $\$ 400$ ve üzeri tutarda dayanıklı tüketim malzemesi alan 323 kişiyle yaptıkları araştırmanın ifade ve boyutlara ait alpha $(\alpha)$ değerleri duygusal uyumsuzluk boyutu için .92, satın almada akılcılık boyutu için .81, kandırılma endişesi boyutu için .86'dır.

\subsection{Uyarlama Çalışması ve Çalışma Grubu}

Bilişsel uyumsuzluk ölçeğinin Türkçeye uyarlanması çalışmasında öncelikle ölçeğin kullanımı için araştırmacılardan (Sweeney vd., 2000) izin alınmıştır. Özgün dili İngilizce olan ölçek Türkçeye çevrilmiş ve bu süreçte Türk Dilinin özellikleri, Türk kültürü ve sosyal yapısı göz önünde bulundurulmuştur. Uyarlama çalışmasında çevirigeri çeviri yöntemi izlenmiştir. Ölçek öncelikle anadili Türkçe olan 3 öğretim üyesi (İngiliz Dili ve Edebiyatı Bölümü, Psikoloji Bölümü ve Turizm Anabilim Dalı) tarafından Türkçeye çevrilmiştir. İncelemeler ve gerekli düzeltmelerin ardından oluşturulan Türkçe form, iki dili de akıcı olarak konuşabilen iki doktora öğrencisi tarafından tekrar İngilizceye çevrilmiştir. Geri çevrilen form, orijinali ile anlam ve biçim yönünden karşılaştırılmıştır (Çapık, Gözüm ve Aksayan 2018). Ölçek konaklama satın alımı yapan örneklem üzerinde kullanılacağı için 'ürün=otelde konaklama' şeklinde değerlendirilmiş ve çevirinin uygunluğunun değerlendirilmesinin ardından da ölçme aracına son şekli verilmiştir. Aynı zamanda ölçek turizm eğitimi ve psikoloji alanlarında 
uzman iki kişi tarafından incelenerek önerileri dikkate alınmıştır. Her bir madde gözden geçirilerek özgün ifadeyi en iyi yansıtan şekliyle kabul edilmiştir. Bilişsel uyumsuzluğu ölçmeyi amaçlayan ifadeler için katılımcılardan Likert Tipi ölçek üzerinden yanıt istenmiştir.

Araştırmaya başlamadan önce Akdeniz Üniversitesi Bilimsel Etik Kurulu'ndan onay alınmıştır. Araştırma verileri, işletme yönetiminin izni sonrasında rezervasyon, ön büro ve misafir ilişkileri birim sorumluları ile iletişimle takip edilen süreçte, otel tercihini yapan misafirlerin otelde bir gece konaklamalarını takip eden günde toplanmıştır. Anket, rezervasyon listelerine göre hareket eden araştırmacılar tarafından, Antalya ve ilçelerindeki Kültür ve Turizm Bakanlığı'ndan belgeli 3,4 ve 5 yıldızlı 26 otel işletmesine gelen bir gece konaklayan 18-75 yaş aralığındaki, zihinsel engeli olmayan, araştırmaya katılmaya gönüllü ve en az okuryazarlık düzeyinde eğitimli olan Türk misafirlere 1 Mart-15 Mayıs 2017 tarihleri arasında uygulanmıştır. Araştırmacı tarafından konaklama işletmelerine bizzat gidilerek misafirlere çalışmanın amacı ve kapsamı hakkında kısa bilgi verildikten sonra anketlerin doldurulması sağlanmıştır. Araştırmaya katılanlardan kimliklerini belirleyici bilgi istenmemiştir. Örnekleme dâhil edilecek katılımcılar, araştırmacı tarafından belirlendiğinden olasılıksız örnekleme yöntemi olan kolayda örnekleme yöntemi kullanılmıştır.

Ölçek adaptasyon çalışmalarında Kline (2011) en az 200 kişilik bir örneklem ile çalışılması gerektiğini belirtirken Bryman ve Cramer (2001) öngörülen asgari örneklem sayısının ölçekte yer alan madde sayısının beş veya on katı olması gerektiğini savunur. Hair'a göre (2010) ise ölçekte yer alan her bir parametrenin en az 10 katılımcı tarafından cevaplanması ve bundan bağımsız olarak veri miktarının en az 100 ve üzeri olması gerekmektedir. Bu çalışmada yer alan örneklem sayısı tüm bu ölçütlerin üzerinde olduğundan, örneklem sayısının yeterli olduğu söylenebilir. Katılımcılara ait bilgiler aşağıda verilmiştir.

Tablo 1: Katılımcıların Demografik Özellikleri

\begin{tabular}{|l|l|l|}
\hline \multirow{4}{*}{ Cinsiyet } & Kadın & 146 \\
\cline { 2 - 3 } & Erkek & 144 \\
\cline { 2 - 3 } & Toplam & 290 \\
\hline \multirow{4}{*}{ Eğitim Durumu } & Illköğretim & 22 \\
\cline { 2 - 3 } & Lise & 137 \\
\cline { 2 - 3 } & Üniversite (Önlisans-Lisans) & 115 \\
\cline { 2 - 3 } & Yüksek Lisans/ Doktora & 16 \\
\cline { 2 - 3 } & Toplam & 290 \\
\hline
\end{tabular}

\section{3. İşlem}

Veri seti için uç değer incelemesi yapılmış, bağımlı ve bağımsız değişkenlere yönelik tek değişkenli uç değerler için .01 düzeyinde anlamlı $Z$ tablo değeri artan ya da azalan sırada kontrol edilmiştir. 3,29'u geçen veriler çıkarılmıştır (Field, 2009). Çok değişkenli uç değerler için yapılan Cook's mesafesi incelemesinde 1'in üzerinde değer bulunmamıştır. Yapılan uygulamalarda çıkarılan 18 kişiye ait anket verisi sonrasında geriye kalan 290 müşteriden toplanan anket verisi üzerinden analizler yapılmıştır.

Ölçek uyarlama çalışmalarında, ölçekteki maddelerin yapısı hakkında var olan hipotez sınandığı için genellikle Doğrulayıcı Faktör Analizi (DFA) kullanılmaktadır 
(Gözüm ve Aksayan, 2003). Bu çalışmada orijinal ölçekteki "ürün" ifadesi yerine "otel" ve ilişkili kavramlar kullanıldığından değişkenler arası ilişkilere dayalı olarak faktörleri keşfetmek amacıyla AFA uygulanmış, sonrasında belirlenmiş olan faktör yapılarının geçerliliğini test etmede kullanılan çok değişkenli bir teknik olan DFA'dan yararlanılmıştır (Hair vd., 2010). DFA, Lisrel 8.8 paket programında ve maksimum olabilirlik (Maximum Likelihood-ML) yöntemi kullanılarak test edilmiştir. Yapı geçerliliği DFA ile sınandıktan sonra birleşme (yakınsama) ve ayrışma geçerlilikleri incelenmiştir. Ölçek adaptasyonunun tüm aşamaları yerine getirilmiş ve dil eşdeğerliği, kapsam/içerik geçerlilikleri de sağlanmıştır.

DFA sürecinde geçerliliğe ilişkin çeşitli model uyum indeksleri elde edilir ve birbirlerine göre güçlü ve zayıf yönlerinin olması nedeniyle model uyumunun ortaya konması için birçok uyum indeksi değerinin birlikte kullanılması önerilir (Büyüköztürk vd., 2004). Bu araştırmada, uyum indeksleri arasında en sık kullanılanlardan Ki-Kare Uyum İyiliği (Chi-Square Goodness of Fit), İyilik Uyum Indeksi (Goodness of Fit Index; GFI), Karşılaştırmalı Uyum İndeksi (Comparative Fit Index; CFI), Normlaştırılmış Uyum Indeksi (Normed Fit Index; NFI) ve Yaklaşık Hataların Ortalama Karekökü (Root Mean Square Error of Approximation; RMSEA) kullanılmıştır. Uyum iyiliği indekslerinden biri olan RMSEA için 0,08'in altı kabul edilebilir değer olarak alınmıştır. Aynı zamanda, ideal bir modelde CFI değerinin 0,95 ve üzeri olması kabul edilebilir uyum indeksidir. GFI için bu değer 0,85 ve üstü iken NFI için 0,90 ve üstü değerler kabul edilebilirdir (Tabachnick ve Fidel, 2001; Schermelleh-Engel vd., 2003). Bu çalışmada, öne sürülen model için tespit edilen RMSEA değeri $0,07, \mathrm{CFI}$, GFI ve NFI değerleri ise sırasıyla $0,98,0,90$ ve 0,97 'dir. Önerilen modelin hesaplanan X2/sd oranının 3 'ten küçük olması mükemmel uyumun, 5'ten küçük olması kabul edilebilir uyumun göstergelerindendir (Sümer, 2000) (x2/sd=3,95). İyi bir uyum indeksi için yukarıda belirtilen değerler göz önünde bulundurulduğunda elde edilen sonuçların Bilişsel Uyumsuzluk Ölçeğinin üç faktör kapsamında iyi düzeyde açıklanabileceğini göstermektedir.

Bilişsel Uyumsuzluk ölçeğinin yakınsama ve ayrışma geçerliliğinin ölçülmesi için madde güvenirliği, yapı güvenirliği ve açıklanan ortalama varyans Fornell ve Larcker (1981)'in yöntemiyle hesaplanmıştır. Ardından ölçeklere ilişkin alt boyutlar arasındaki ilişkinin kuvvetini (düşük-orta-yüksek) ve yönünü (pozitif-negatif) belirleyebilmek için Pearson Korelasyon Analizinden yararlanılmıştır.

\section{Bulgular}

\subsection{Dil ve Kapsam Geçerliliği}

Yukarıda açıklanan çeviri-tekrar çeviri yöntemi sonrasında, dil eşdeğerliğini sağlayabilmek amacıyla İngilizce ve Türkçeyi bilen Akdeniz Üniversitesi İngiliz Dili Edebiyatı ve Yabancı Diller Yüksekokulu öğretim elemanlarından oluşan 30 kişilik gruba ilk önce ölçeğin İngilizce formu uygulanmıştır. Bilişsel uyumsuzluk ölçeği otel hizmeti satın alımına uygun olduğu için bu ölçeğin yönergesinde 'Lütfen bu bölümde en son konaklama yaptığınız otel veya pansiyonu düşünerek cevap veriniz' ifadesi kullanılmıştır. 2 hafta sonrasında aynı kişilere uygulanan Türkçe formun bilişsel uyumsuzluk ölçeği yönergesinde ise 'Lütfen bu bölümdeki soruları size İngilizce olarak sunulan bir önceki anketteki otel/pansiyon satın alımınızı düşünerek cevaplayınız.' ifadesi kullanılmıştır. Elde edilen sonuçlar arasındaki ilişki, Eş Örneklem T-Testi ile incelenmiştir. Öncelikle bu testin yapılabilmesi için verilerin normalliğinin tespitinde çarpıklık ve basıklık değerleri incelenmiş, verilerin normal dağılım gösterdiği sonucuna varılmıştır. Eş örneklem testi sonucunda anlamlılık (p) değeri .752 olarak belirlenmiştir. 
Buna göre ölçeğin iki formu arasında algılanış bakımından fark olmadığı sonucuna ulaşılmıştır (Field, 2009).

Kapsam (içerik) geçerliliği için uzman görüşlerine (Turizm, Psikoloji, İngiliz Dili ve Edebiyatı, İngiliz Dili ve Edebiyatı öğretim üyeleri) başvurulmuş ve ölçekte yer alan ifadelerin ve sözcük yapılarının anlaşılırlığı, terminolojisi, kültürel uygunluğu değerlendirilmiş ve üzerinde fikir birliği sağlanmıştır.

\subsection{Açımlayıcı Faktör Analizi (AFA)}

Faktör sayısına herhangi bir sınırlama getirmeden veri setine temel bileşenler faktör analizi, varimax döndürme yöntemiyle uygulanmıştır. Örneklemden elde edilen verilerin kabul edilebilir sınırlar içinde olduğunu belirlemek için yapılan Kaiser-Meyer-Olkin (KMO) değerinin .914 çıkması, örneklem büyüklüğünün faktör analizi için kabul edilebilir düzeyde olduğunu göstermektedir. Bartlett'sTest of Sphericity değerinin 2830,251 olması, .00 düzeyinde istatistiki olarak anlamlı olduğunu ve dağılımın normallik düzeyinin faktör analizinin uygulanma koşulunu karşıladığını göstermektedir.

Tablo 2: Türkçe Bilişsel Uyumsuzluk Ölçeğinin AFA ve Güvenilirlik Analizi Sonuçları

\begin{tabular}{|c|c|c|c|c|}
\hline Maddeler & 离 & 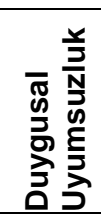 & 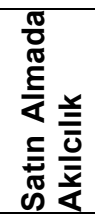 & 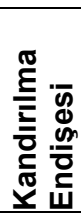 \\
\hline Bu otele geldikten sonra büyük hayal kırıklığına uğradım. & .552 & .382 & & \\
\hline Bu otele geldikten sonra çaresiz hissettim. & .765 & .796 & & \\
\hline Bu otele geldikten sonra bunalıma girdim. & .838 & .854 & & \\
\hline Bu otele geldikten sonra kendimi fiziksel olarak hasta hissettim. & .765 & .800 & & \\
\hline Bu otele geldikten sonra kendimi boşlukta hissettim. & .754 & .765 & & \\
\hline $\begin{array}{l}\text { Bu otelde konaklamaya gerçekten ihtiyacım var mıydı merak } \\
\text { ediyorum. }\end{array}$ & .782 & & .813 & \\
\hline $\begin{array}{l}\text { Herhangi bir otelde konaklama yapmalı mıydım merak } \\
\text { ediyorum. }\end{array}$ & .765 & & .792 & \\
\hline Tercihimin doğru olup olmadığını merak ediyorum. & .808 & & .817 & \\
\hline $\begin{array}{lllll}\text { Bu otele rezervasyon yaptırmakla doğru şeyi yapıp } \\
\text { yapmadığımı merak ediyorum. }\end{array}$ & .778 & & .706 & \\
\hline $\begin{array}{l}\text { Bu otele geldikten sonra, aptal yerine konulup konulmadığımı } \\
\text { merak ettim. }\end{array}$ & .839 & & & .788 \\
\hline $\begin{array}{l}\text { Bu otele geldikten sonra, kandırılıp kandırılmadığımı merak } \\
\text { ettim. }\end{array}$ & .887 & & & .834 \\
\hline $\begin{array}{l}\text { Bu otele geldikten sonra, yaptığım konaklama sözleşmesinde } \\
\text { yanlış bir şey olup olmadığını merak ettim. }\end{array}$ & .826 & & & .772 \\
\hline \multicolumn{2}{|l|}{ Öz değer } & 7,24 & 1,26 & 0,81 \\
\hline \multicolumn{2}{|l|}{ Açıklanan Varyans } & 60,36 & 10,54 & 6,81 \\
\hline \multicolumn{2}{|l|}{ Cronbach Alfa } &, 876 & ,912 &, 915 \\
\hline
\end{tabular}

$K M O=.914$, Genel $\alpha=.937$, Bartlett's Test of Sphericity $=2830,251$, Toplam Açıklanan Varyans $=77,72, p<$ .001

Ölçeğin güvenilirlik katsayısı .937'dir ve yüksek derecede güvenilir olduğunu göstermektedir. Değişkenlerden herhangi birinin çıkarılması sonucunda güvenilirlik katsayısı ortalamanın üzerinde artmadığı için bu şekilde korunması gerekmektedir. Daha sonraki aşamada 12 değişken üzerinden yapılan faktör analizinde 3 alt faktör 
elde edilmiştir. Bu 3 faktör, toplam varyansın \%77,72'sini açıklamaktadır. Her bir faktör grubunun güvenilirliğinin .80 değerinin üstünde olması, her bir faktör grubunun yüksek derecede güvenilir sınırlar içinde yer aldığı sonucunu ortaya koymaktadır (Kozak, 2017: 150).

Değişkenlerin faktör yükleri, ait olduğu faktör grubuna yaptıkları katkıyı gösterir. Mutlak değer olarak .60 ve üstü yük değeri yüksek; 0.30-0.59 arası yük değeri orta düzeyde büyüklükler olarak tanımlanabilir (Büyüköztürk, 2002: 474). Analiz sonuçlarına göre bilişsel uyumsuzluk ölçeğinin ilk sorusu orta düzeyde faktör yüküne, diğerleri ise yüksek düzeyde faktör yüküne sahiptir.

\subsection{Yapı Geçerliliğgi}

\subsubsection{Doğrulayıcı Faktör Analizi (DFA)}

AFA'dan sonra 3 boyuttan ve 12 maddeden oluşan BUÖ, DFA ile test edilmiştir. Bu amaçla öncelikle modelin tanımlanması gerekmektedir. Modelin tanımlanması, yapılan analizin kuramsal bir altyapıya dayandırılmasıdır. Bu aşamada bilişsel uyumsuzluk konusunda geliştirilen kavramsal çerçeveden ve bu çerçeve temel alınarak gerçekleştirilen AFA sonuçlarından yararlanıımıştır. AFA aşamasında belirlenen faktör yapıları, path diyagramlarından yararlanılarak ölçme modeli biçiminde tasarlanmıştır. Bu amaçla kurulan ölçme modeli Şekil 1'de görülmektedir. Diyagramda öncelikle, her bir maddenin kendi örtük değişkenini ne kadar iyi temsil ettiğine ilişkin standardize edilmiş değerler incelenmiştir.

\section{Şekil 1: Türkçe Bilişsel Uyumsuzluk Ölçeği İçin DFA Sonuçları (Standartlaştırılmış Değerler)}

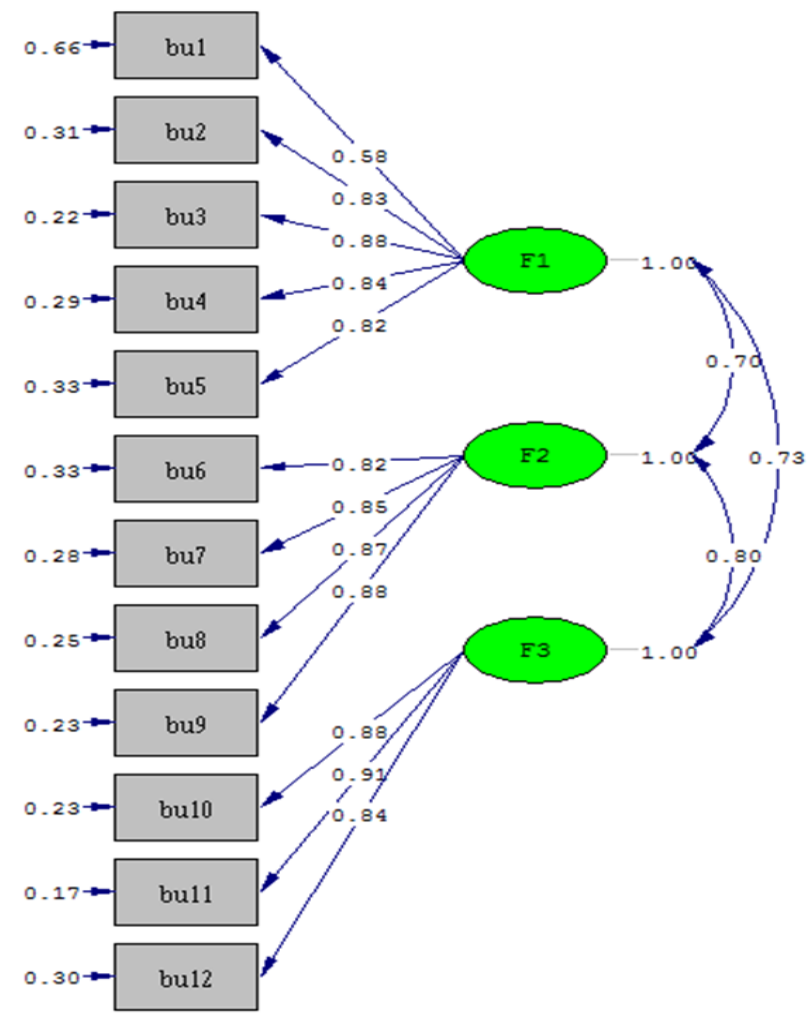


Modelde yer alan Faktör 1 (Duygusal Uyumsuzluk), Faktör 2 (Satın Almada Akılcılık), Faktör 3 (Kandırıma Endişesi) gözlenen değişkenleri ifade etmektedir. Faktör ağırlıkları maksimum olabilirlik metoduna göre standardize edilmiş katsayı tahminleri olarak hesaplanmıştır. Bütün katsayılar .05 önem derecesinde anlamlı bulunmuştur. Tablo 3: Bilişsel Uyumsuzluk Ölçeğinde Yer Alan Maddelere İlişkin DFA
Sonuçları

\begin{tabular}{|l|l|l|l|}
\hline Maddeler & $\lambda$ & $\mathbf{t}$ & $\mathbf{S E}$ \\
\hline Bu otele geldikten sonra büyük hayal kırıklığına uğradım. & 0.58 & 10.48 & 11.50 \\
\hline Bu otele geldikten sonra çaresiz hissettim. & 0.83 & 17.08 & 9.68 \\
\hline Bu otele geldikten sonra bunalıma girdim. & 0.88 & 18.69 & 8.35 \\
\hline Bu otele geldikten sonra kendimi fiziksel olarak hasta hissettım. & 0.84 & 17.38 & 9.46 \\
\hline Bu otele geldikten sonra kendimi boşlukta hissettim. & 0.82 & 16.62 & 9.96 \\
\hline Bu otelde konaklamaya gerçekten intiyacım var mıydı merak ediyorum. & 0.82 & 16.66 & 10.04 \\
\hline Herhangi bir otelde konaklama yapmalı mıydım merak ediyorum. & 0.85 & 17.57 & 9.62 \\
\hline Tercihimin doğru olup olmadığını merak ediyorum. & 0.87 & 18.15 & 9.08 \\
\hline $\begin{array}{l}\text { Bu otele rezervasyon yaptırmakla doğru şeyi yapıp yapmadığımı merak } \\
\text { ediyorum. }\end{array}$ & 0.88 & 18.60 & 8.70 \\
\hline Bu otele geldikten sonra, aptal yerine konulup konulmadığımı merak ettim. & 0.88 & 18.48 & 8.55 \\
\hline Bu otele geldikten sonra, kandıııı kandırımadığımı merak ettim. & 0.91 & 19,59 & 7.14 \\
\hline $\begin{array}{l}\text { Bu otele geldikten sonra, yaptığım konaklama sözleşmesinde yanlış bir şey } \\
\text { olup olmadığını merak ettim. }\end{array}$ & 0.84 & 17.18 & 9.68 \\
\hline
\end{tabular}

$\lambda$ : Faktör Yükü, SE: Hata Varyansı

DFA sonuçlarına göre, faktör yükleri $(\lambda) .58$ ile .91 arasında değişmektedir. Değişkenlerin faktör yükleri, ait olduğu faktör grubuna yaptıkları katkıyı gösterir. .60 ve üstü yük değeri yüksek; .30-.59 arası yük değeri orta düzeyde büyüklük olarak tanımlanabilir (Büyüköztürk, 2002: 474). Ayrıca tüm maddelere ilişkin t değerleri de en az 1,96 olma koşulunu sağlamıştır ve anlamlıdır.

Tablo 4: Üç Boyutlu Bilişsel Uyumsuzluk Ölçme Modeline İlişkin Sonuçlar

\begin{tabular}{|l|c|l|l|l|l|l|l|}
\hline Model & \multicolumn{1}{|c|}{$\chi^{2}$} & sd & $\chi^{2} /$ sd & NFI & GFI & CFI & RMSEA \\
\hline $\begin{array}{l}\text { Üç Faktörlü } \\
\text { Yapı }\end{array}$ & 201,86 & 51 & 3,95 & 0.97 & 0.90 & .98 & .07 \\
\hline Ölçütler & & & $\leq 5$ & $\geq .90$ & $\geq .90$ & $\geq .95$ & $\leq .08$ \\
\hline
\end{tabular}

X2: Chi-Square Goodness of Fit, sd: Serbestlik Derecesi (df), NFI: Normed Fit Index, GFI: Goodness of Fit Index, CFI: Comperative Fit Index, RMSEA: Root Mean Square Error of Approximation

Modele ilişkin hesaplanan $\chi^{2}$,sd oranının 3'ten küçük olması mükemmel uyumun, 5 'ten küçük olması kabul edilebilir uyumun göstergelerindendir (Sümer, 2000). RMSEA, GFI, NFI ve CFI değerleri de gerekli ölçütleri sağlamıştır. 
Böylece Türkçe Bilişsel Uyumsuzluk Ölçeğinde yer alan 12 maddeyle kurulan 3 boyutlu yapının model-veri uyumuna sahip olduğu sonucuna ulaşılmıştır. Yapılan DFA, ölçeğin son halini 12 madde ve 3 alt boyut olarak mümkün kılmaktadır. Modele dâhil edilen tüm maddelerin model ile uyumlu olduğu söylenebilir. Her faktör, içinde yer alan soruları doğru şekilde temsil etmektedir. Bilişsel uyumsuzluk ölçme modeline ilişkin uyum indeksleri ve temel parametre tahminleri, modelin verilerle uyum içerisinde olduğunu göstermektedir. Bu bulgular ifadelerin faktörler tarafından doğru açıklandığının ve ölçeğin yapı geçerliliğinin bir kanıtı olarak kabul edilebilir.

\subsection{Birleşme (Yakınsama) ve Ayrışma Geçerliliği}

DFA'nın bu aşamasında yakınsama ve ayrışma geçerliliklerinin tespiti için ölçüm modeline ait ilişki katsayıları, yapı güvenirliliği, açıklanan varyans ve korelâsyon değerleri hesaplanmış ve Tablo 4'te sunulmuştur. Ortalama açıklanan varyans (AVE) değerinin .50'ye eşit veya daha yüksek olması gerekir (Fornell ve Larcker, 1981). Yapı güvenilirliği için ise .70'den yüksek değerler kabul edilebilirdir (Hair vd., 2010). Yapı güvenirliliği ve AVE değerleri incelendiğinde (iç tutarlılık>.70 ve AVE>.50) koşulların sağlandığı görülmektedir. Her bir boyut için yapı güvenilirliği değerleri ve açıklanan varyans oranları oldukça yüksektir. Buna göre Türkçe Bilişsel Uyumsuzluk Ölçeğini oluşturan boyutların içsel tutarlııklarının ve yapıyı açıklama güçlerinin yeterli olduğu söylenebilir. Bu güvenilirlik değerleri aynı zamanda yapıyı oluşturan değişkenlerin kendi aralarındaki yüksek korelasyon ilişkisini gösteren birleşme (yakınsama) geçerliliğinin delilleri olarak görülmektedir (Hair vd., 2010). Dolayısıyla ölçeğe ilişkin tüm yapılar birbirleriyle belirli düzeyde ilişkili ve ölçeğin birer parçasıdır.

Tablo 5: Bilişsel Uyumsuzluk Ölçeğinin Faktör Yapı Güvenilirliği, Faktörler Arası Korelasyon ve AVE Değerleri

\begin{tabular}{|l|l|l|l|l|l|}
\hline & $\begin{array}{l}\text { Yapı } \\
\text { Güvenilirliği }\end{array}$ & AVE & $\begin{array}{l}\text { Duygusal } \\
\text { Uyumsuzluk }\end{array}$ & $\begin{array}{l}\text { Satın } \\
\text { Almada } \\
\text { Akılcılık }\end{array}$ & $\begin{array}{l}\text { Kandırılma } \\
\text { Endişesi }\end{array}$ \\
\hline $\begin{array}{l}\text { Duygusal } \\
\text { Uyumsuzluk }\end{array}$ & 0,85 & 0,63 & 1 & 1 & \\
\hline $\begin{array}{l}\text { Satın } \\
\text { Almada } \\
\text { Akılcılık }\end{array}$ & 0,86 & 0,73 & $0,51\left(^{* *}\right)$ & 1 & 1 \\
\hline $\begin{array}{l}\text { Kandırılma } \\
\text { Endişesi }\end{array}$ & 0,84 & 0,76 & $0,52\left(^{* *}\right)$ & $0,64\left({ }^{* *}\right)$ & 1 \\
\hline
\end{tabular}

**.01 düzeyinde anlamlı

AVE: Average Variance Extracted (Çıkarılan Ortalama Varyans)

Bilişsel uyumsuzluk boyutları arasındaki korelâsyon değerleri .01 düzeyinde anlamlıdır ve en büyük korelasyon değeri .64'tür. Hem uyum indeks değerleri hem de korelâsyon değerleri gerekli şartları sağladığı için bilişsel uyumsuzluk ölçeğinde yakınsama geçerliliğinin varlığından söz edilebilmektedir.

Birleşme (yakınsama) geçerliliğinden sonra ayrışma geçerliliği test edilmiştir. Ayrışma geçerliliği farklı yapılar arasındaki ayrışma derecesini gösterir. Yapının geçerli olabilmesi için yapıyı oluşturan değişkenlerin diğer değişkenlerle düşük korelasyon ilişkisini gösteren ayrışma geçerliliğini sağlaması gerekmektedir. Bunun için temel koşul ise bir yapıya ait açıklanan varyansın o yapının diğer yapılarla arasındaki en yüksek korelâsyon katsayısının karesinden büyük olmasıdır (Fornell ve Larcker, 1981). Kandırılma endişesi faktörünün diğer yapılarla arasındaki en büyük korelâsyonun satın 
almada akılcılık faktörü ile olduğu ve değerinin .64 düzeyinde olduğu belirlenmiştir. Kandırılma endişesi faktörünün AVE değeri .76 olarak hesaplandığından $\left(.76>.64^{2}\right)$ ayrışma geçerliliği sağlanmıştır. Diğer boyutlara ilişkin değerler incelendiğinde de tüm yapıların ayrışma geçerliliklerinin sağlanmış olduğu görülmektedir. Böylece ölçeğe ilişkin faktörlerin tümünün bağımsız birer yapı olduğu söylenebilir.

\subsection{Bilişsel Uyumsuzluk Ölçeğinin Güvenilirlik Analizi}

Ölçeğin güvenilirliği, iç tutarlılığı gösteren Cronbach Alpha $(\alpha)$ değerleri ile incelenmiştir. Ölçeğin güvenilirlik katsayısı .93'tür ve her bir faktör grubunun güvenilirliğinin .80 değerinin üstünde olması, ölçeğin ve her bir faktör grubunun yüksek derecede güvenilir sınırlar içinde yer aldığı sonucunu ortaya koymaktadır (Kozak, 2017). Ölçek boyutlarına ait Cronbach alpha iç tutarlılık katsayıları aşağıda belirtilmiştir.

\section{Tablo 6: Bilişsel Uyumsuzluk Ölçeğinin Güvenilirlik Analizi Sonuçları}

\begin{tabular}{|l|l|}
\hline Boyutlar & Cronbach Alpha \\
\hline Duygusal Uyumsuzluk & .87 \\
\hline Satın Almada Akılcılık & .91 \\
\hline Kandırılma Endişesi & .91 \\
\hline \multicolumn{2}{|c|}{ Genel Cronbach Alpha=.937, $p<.001$}
\end{tabular}

\section{Tartışma ve Sonuç}

Bu çalışmada Sweeney, Hausknecht ve Soutar'ın (2000) karar sonrası uyumsuzluğun duygusal ve bilişsel yönlerini ölçmek için geliştirdikleri daha sonra Sweeney ve Soutar (2006) tarafından kısaltılan Bilişsel Uyumsuzluk Ölçeği Türkçeye uyarlanmış, geçerlik ve güvenirliği incelenmiştir. Bu doğrultuda 12 maddelik özgün ölçek Türkçeye çevrilmiş, maddeler ifade ve amaca uygunluk bakımından uzmanların görüşleri doğrultusunda oluşturulmuştur. Ölçek, Antalya ve ilçelerindeki Kültür ve Turizm Bakanlığı'ndan belgeli 3, 4 ve 5 yıldızlı 26 otel işletmesine gelen 290 Türk misafire otelde bir gece konaklamalarını takip eden günde uygulanmıştır. Bir gece konaklamış olmalarının tercih edilme sebebi, bu aşamada diğer alternatiflerin ortadan kalkmış olmasıyla beraber henüz algının deneyim sonrasında memnuniyet ya da memnuniyetsizliğe dönüşmemiş olmasıdır.

290 turistten toplanan verilere yapılan faktör analizinde 12 maddelik ölçek duygusal, satın almada akılcılık ve kandırıma endişesi olmak üzere üç faktörden oluşmuştur. Ölçeğin güvenirlik katsayısı 0,93 olarak hesaplanmıştır. Alt boyutlar için Cronbach Alpha güvenirlik katsayıları duygusal boyut için .87, satın almada akılcılık boyutu için .91 ve kandırılma endişesi boyutu için .91'dir. Bu 3 faktör, toplam varyansın $\% 77,72$ 'sini açıklamaktadır. Her bir faktör grubunun güvenilirliğinin .80 değerinin üstünde olması, her bir faktör grubunun yüksek derecede güvenilir sınırlar içinde yer aldığı sonucunu ortaya koymaktadır. Sonuç olarak, Bilişsel Uyumsuzluk Ölçeğinin Türkçe Formunun kabul edilebilir değerlerde güvenilir ve geçerli bir ölçme aracı olduğu söylenebilir (Ek 1).

Tatilin geçirileceği destinasyon ve konaklama işletmesi, bireyler için oldukça önemli bir karardır. Tüm alternatifler arasında seçim yapıldıktan sonra bir diğerini seçmemiş olmanın yaratabileceği uyumsuzluk, işletmeler açısından müşteri memnuniyeti için çaba gösterme sürecinin başlangıcı sayılmalıdır. İşletmeler, rezervasyon aşamasından sonra müşterilerin diğer alternatifleri düşünme yani 
seçimleri konusunda bilişsel uyumsuzluk yaşayabilme intimallerini göz önüne alıp seçimleri konusunda güvenlerini artırmak yönünde müşterilerle iletişime geçebilir, yaptıkları seçimin isabetli olduğu konusunda ikna çalışmaları yapabilirler. Çünkü tüketicinin yaptığı seçimi sorgulaması ve yanlış karar vermiş olabileceğiyle ilgili şüphe duyması olarak da tanımlanabilen bilişsel uyumsuzlukta bireyin kendine güveni çok önemlidir. Kendine ve kararlarına güvenen tüketiciler bilişsel uyumsuzluğu daha az deneyimlerler. Pek çok araştırma, yaptığı seçimle ilgili olarak tüketicinin kendine olan güvenini arttırmanın uyumsuzluğu azaltabileceğini ortaya koymuştur (Soutar ve Sweeney, 2003; Hennig-Thurau vd., 2002; Nandan, 2005; Szymanski ve Henard, 2001; Keng ve Liao, 2013). Bu anlamda bu araştırmada adaptasyonu yapılan ölçme aracı gibi müşterilerin bilişsel uyumsuzluk düzeylerini tespit edecek anket uygulamaları yapılabilir ve alternatifler arasında kafası karışmış müşterilerin varlığı halinde müşteri memnuniyeti yaratmaya yönelik uygulamalar geliştirilebilir. Bilişsel uyumsuzluğun azaltılmasının müşteri memnuniyetinin oluşması için gerekli ön koşul olduğu, yeniden satın alma niyeti, marka sadakati, şikâyet, iade davranışı ve sözleşme iptallerinin satın alma sonrası bilişsel uyumsuzlukla ilişkisi göz önüne alındığında, uyumsuzluğun azaltılmasına yönelik çabaların önemli olduğu düşünülmektedir.

Uyumsuzluk bu ve benzeri ölçme araçlarıyla tespit edilebileceği gibi müşteri şikâyetleri de bilişsel düzeyde yaşanan uyumsuzluğun göstergesi olarak ortaya çıkabilmektedir (Keng ve Liao, 2009). Müşteri yaşadığı uyumsuzluğu şikâyet olarak dışa vursun ya da vurmasın önceki alternatifler arasında yer alan işletmeyle ilgili olarak "x oteli tercih etseydim bu durumu yaşamazdım" algısı devam edecektir. Bu anlamda her şikâyet yani işletmeler açısından tüketiciyle her karşılaşma, müşteriyle tehlikeye giren ilişkiyi düzeltmek, güven ve değer yaratmak için bir fırsattır. Müşteriyi yaşadığı uyumsuzluğu dışa vurması için teşvik etmek ve bu süreci çok iyi yönetmek gerekir. İşletmenin şikâyetler karşısındaki tutumu, müşteri ilişkilerinde uyguladığı politika ve uyumsuzluğun azaltılmasına yönelik eylemleri müşterinin memnun ya da memnuniyetsiz olarak ayrılma durumunu şekillendirecektir. Şikâyet sahibi kimselerin çalışanlar tarafından önemsenmeleri durumunda ve en kısa sürede çözüme kavuşturulduğunda, memnuniyetsizlikleri memnuniyete ve güvene dönüşebilir (Heung ve Lam 2003: 287).

Diğer sektörlerde olduğu gibi hizmet sektöründe de nihai amaç müşteri memnuniyeti ve sadakatidir. Bu değişkenleri etkileyen faktörler, bugüne kadar üzerinde oldukça fazla araştırma yapılan konulardır. Fakat alan araştırmasında görülmektedir ki müşteri memnuniyeti üzerinde en az hizmet kalitesi kadar etkili olan bilişsel uyumsuzluk kavramı bugüne kadar üzerinde yeterince araştırma yapılmış bir konu değildir. Bu anlamda bu çalışmanın ve uyarlanan ölçeğin alan yazına ve sektörel bilgi birikimine katkı sağlayacağı düşünülmektedir.

Araştırmada nicel araştırma yöntemi kullanılmıştır. Nicel araştırmanın, genelleştirilebilir sonuçlar üretmesi, farklı gruplar arasında karşılaştırmaya fırsat vermesi ve belirli bir yapı içindeki ilişkilerin incelenmesine yardımcı olmasının yanında, mükemmel nitelik ve sayıda örneklem almanın güçlüğü, mükemmel ölçüm şartlarının her zaman sağlanamaması, ölçme aracının önyargıyı da yansıtma intimali gibi sınırlılıkları mevcuttur. Ayrıca bilişsel uyumsuzluk nesnel olarak değerlendirilmesi güç olan kavram olduğundan kişinin kendi beyanına dayalı ölçüm araçları ile değerlendiriyor olmanın sınırlıı̆ııı taşımaktadır. Ölçek adaptasyonunun basamakları, dil geçerliliği prosedürü ve analizleri katı bir şekilde izlenmiş ve güvenilirlik sonuçları bu araştırmayı devam ettirmek için yeterince yüksek bulunmuştur. Bununla birlikte, yapılan bu çalışmanın farklı örneklemlerle de gerçekleştirilmesi ölçeğin güvenilirliğinin ve geçerlilik sınanması açısından önemlidir. Araştırmanın diğer bir kısıtı ise hizmet 
sektöründe bu ölçeği kullanan araştırma bulgularına rastlanmamış olması dolayısıyla sonuçların karşılaştırılamamış olmasıdır. Ayrıca, Bilişsel Uyumsuzluk Ölçeğinin hizmet sektörü açısından müşteri memnuniyeti, marka sadakati, yeniden satın alma, müşteri ilişkileri ve şikâyet yönetimi gibi değişkenlerle ilişkisinin çalışılmasının da alan yazına önemli katkılar sunabileceği düşünülmektedir. Böylece Türkiye'de faaliyet gösteren firmaların, tüketicilerin bilişsel uyumsuzluk algılarının bu değişkenlerle ne derece etkileşim içinde bulunduğunu keşfetmelerinin rekabetçi piyasa koşullarında onlara avantaj sağlayacağı düşünülmektedir.

\section{Kaynakça}

Bawa, A. ve Kansal P. (2008). "Cognitive Dissonance And The Marketing Of Services: Some Issues". Journal of Services Research, 8(2): 31-51.

Bell, G. D. (1967). "The automobile buyer after the purchase". The Journal of Marketing, 31(3): 12-16.

Bolia, B., Jha, S. ve Jha, M. K. (2016). "Cognitive dissonance: a review of causes and marketing implications". Researchers World, 7(2): 63-76.

Bryman A. ve Cramer D. (2001). Quantitative Data Analysis with SPSS Release 10 for Windows: A Guide for Social Scientists. London: Routledge.

Büyüköztürk, Ş., Akgün, Ö. E., Kahveci, Ö. ve Demirel, F. (2004). "Güdülenme ve Öğrenme Stratejileri Ölçeğinin Türkçe Formunun Geçerlik ve Güvenirlik Çalışması". Kuram ve Uygulamada Eğitim Bilimleri, 4(2): 207-239.

Cummings, W. H. ve Venkatesan, M. (1976). "Cognitive Dissonance and Consumer Behavior: A Review of the Evidence". Journal of Marketing Research, 13(3): 303-308.

Çapık, C., Gözüm, S. ve Aksayan, S. (2018). "Kültürlerarası ölçek uyarlama aşamaları, dil ve kültür uyarlaması: Güncellenmiş rehber". Florence Nightingale Journal of Nursing, 26(3): 199-210. https://doi.org/10.26650/FNJN397481

Donnely Jr, J. H. ve Ivancevich, J. M. (1970). "Post-purchase reinforcement and backout behavior". JMR, Journal of Marketing Research (pre-1986), 7(3): 399-400.

Festinger, L. (1957). A theory of cognitive dissonance, Evanston, IL: Row \& Peterson.

Field, A. (2009). Discovering Statistics Using IBM SPSS Statistics. London, United Kingdom.

Fornell, C. ve Larcker, D. F. (1981). "Evaluating structural equation models with unobservable variables and measurement error". Journal of Marketing Research, 18: 39-50.

Gözüm, S. ve Aksayan, S. (2003). "Kültürlerarası Ölçek Uyarlaması İçin Rehber II: Psikometrik Özellikler ve Kültürlerarası Karşılaştırma". Hemşirelikte Araştırma Geliştirme Dergisi, 5(1): 3-14.

Hair, J. F., Anderson, R. E., Babin, B. J. ve Black, W. C. (2010). Multivariate Data Analysis: A Global Perspective (Vol. 7). Upper Saddle River, NJ: Pearson.

Hausknecht, D. R., Sweeney, J. C., Soutar, G. N. ve Johnson, L. W. (1998). "After I Had Made The Decision, I...: Toward a Scale to Measure Cognitive Dissonance". Journal of Consumer Satisfaction, Dissatisfaction and Complaining Behavior, 11: 119-127.

Hennig-Thurau, T., Gwinner, K. P. ve Gremler, D. D. (2002). "Understanding relationship marketing outcomes an integration of relational benefits and relationship quality". Journal of Service Research, 4(3): 230-247.

Hunt, S. D. (1970). "Post-transaction communications and dissonance reduction". The Journal of Marketing, 34(3): 46-51.

Keng, C. J. ve Liao, T. H. (2009). "Consequences of postpurchase dissonance: The mediating role of an external information search". Social Behavior and Personality: An International Journal, 37(10): 1327-1339. 
Keng, C. J. ve Liao, T. H. (2013). "Self-confidence, anxiety, and post-purchase dissonance: a panel study". Journal of Applied Social Psychology, 43(8): 16361647.

Kim, Y. S. (2011). "Application of the cognitive dissonance theory to the service industry". Services Marketing Quarterly, 32(2): 96-112.

Kline, R.B. (2011). An Easy Guide to Factor Analysis. New York: The Guilford Press.

Koller, M. ve Salzberger, T. (2007). "Cognitive Dissonance as a Relevant Construct Throughout The Decision-Making and Consumption Process-An Empirical Investigation Related to a Package Tour". Journal of Customer Behaviour, 6(3): 217-227.

Kotler, P. ve Armstrong, G. (2012). Principles of marketing. 14. Basım, Pearson Int. Edt., New Jersey.

Kozak, M. (2017). Bilimsel Araştırma: Tasarım, Yazım ve Yayım Teknikleri. 3. Basım, Detay Yayıncılık, Ankara.

Menasco M. B. ve Hawkins D. I. (1978). "A Field Test of the Relationship between Cognitive Dissonance and State Anxiety". Journal of Marketing Research, 15(4): 650-655.

Milliman, R. E. ve Decker, P. J. (1990). "The use of post-purchase communication to reduce dissonance and improve direct marketing effectiveness". The Journal of Business Communication, 27(2): 159-170.

Mittelstaedt, R. (1969). "A dissonance approach to repeat purchasing behavior". Journal of Marketing Research, 6(4): 444-446.

Nandan, S. (2005). "An exploration of the brand identity-brand image linkage: A communications perspective". Journal of Brand Management, 12(4): 264-278.

Oliver R. L. (1997). Satisfaction: A behavioral perspective on the consumer. New York: McGraw-Hill.

Soutar, G. N. ve Sweeney, J. C. (2003). "Are There Cognitive Dissonance Segments?". Australian Journal of Management, 28(3): 227-249.

Schermelleh-Engel, K., Moosbrugger, H. ve Müller, H. (2003). "Evaluating the Fit of Structural Equation Models: Tests of Significance and Descriptive Goodness-ofFit Measures". Methods of Psychological Research, 8(2): 23-74.

Sümer, N. (2000). "Yapısal eşitlik modelleri: Temel kavramlar ve örnek uygulamalar". Türk Psikoloji Yazıları, 3(6): 49-74.

Sweeney, J. C., Hausknecht, D. ve Soutar, G. N. (2000). "Cognitive Dissonance after Purchase: A Multidimensional Scale". Psychology \& Marketing, 17(5): 369-385.

Sweeney, J. C. ve Soutar, G. N. (2006). "A Short Form of Sweeney, Hausknecht and Soutar's Cognitive Dissonance Scale". In J. Kennedy ve L. Di Milia (Ed.), 2006 Proceedings of the 20th Annual Conference of the Australian and New Zealand Academy of Management. Sydney, Australia: Central Queensland University.

Szymanski, D. M. ve Henard, D. H. (2001). "Customer satisfaction: A meta-analysis of the empirical evidence". Journal of the Academy of Marketing Science, 29: 1635.

Tabachnick, B.G. ve Fidell, L.S. (2001). Using Multivariate Statistics. 4th Edition, Allyn and Bacon, Boston.

Tanford, S. ve Montgomery, R. (2015). "The effects of social influence and cognitive dissonance on travel purchase decisions". Journal of Travel Research, 54(5): 596-610.

Telci, E. E., Maden, C. ve Kantur, D. (2011). "The theory of cognitive dissonance: A marketing and management perspective". Procedia Social and Behavioral Sciences, 24: 378-386.

Yücel, E. (2017). Turistlerin Satın Alma Sonrası Bilişsel Uyumsuzluk Düzeylerinin Incelenmesi. Yayımlanmamış Doktora Tezi. Akdeniz Üniversitesi Sosyal Bilimler Enstitüsü, Antalya. 
Yücel, E. (2018). Leon Festinger'in Bilişsel Uyumsuzluk Kuramı. Anı Yayıncılık, Ankara.

Yücel, E. ve Çizel, B. (2018). "Bilişsel Uyumsuzluk Teorisi Üzerine Kavramsal Bir İnceleme: Satın Alma Perspektifi", Journal of Yasar University, 13(50): 150-163. 